\title{
Gender participation in maize production system in Tribal areas of Udaipur district, Rajasthan
}

\author{
HARSHITA JAIN, SUMAN SINGH AND HEMU RATHORE
}

Received: 20.05.2017; Revised: 01.11.2017; Accepted: 15.11.2017

See end of the paper for authors' affiliations

\section{HARSHITA JAIN}

Department of Family Resource

Management, College of Home Science,

Maharana Pratap University of

Agriculture and Technology, UDAIPUR

(RAJASTHAN) INDIA

Email : jainharshita24@gmail.com
ABSTRACT : Women in agriculture play a vital role in wide range of activities, thereby contributing to sustainable agricultural development. To achieve inclusive agricultural growth, empowering women by having comprehensive understanding about work participation, gender issues, drudgery and health and nutritional status is necessary. The study was conducted in tribal development block of Udaipur district namely Kherwara. Data were collected from 160 tribal farm families by a pre-designed interview schedule. Different socio-personal characteristics revealed that most of the tribal women were in older age group, belonged to nuclear and not heading the family, illiterate and engaged in all type of agricultural activities and rearing small herd of livestock. Based on the study it was seen that farm women's participation was seen highest in removing of stalk, weeding, harvesting and post harvesting activities. The reason underlying may be that selected area have highest male migration rate for alternate employment and due to this women are more involved in all types of farm activities except ploughing and leveling.

KEY WORDS: Tribal, Gender participation, Maize production system

HOW TO CITE THIS PAPER : Jain, Harshita, Singh, Suman and Rathore, Hemu (2017). Gender participation in maize production system in Tribal areas of Udaipur district, Rajasthan. Asian J. Home Sci., 12 (2) : 570-573, DOI: 10.15740/HAS/AJHS/12.2/570-573. 